M. I. Ivanova ${ }^{1}$, Dr. Sc. (Econ.), Assoc. Prof., orcid.org/0000-0002-1130-0186,

S. O. Faizova ${ }^{2}$, Cand. Sc. (Econ.), Assoc. Prof., orcid.org/0000-0002-7243-0726,

M. V. Boichenko ${ }^{1}$, Dr. Sc. (Econ.), Assoc. Prof., orcid.org/0000-0002-9874-3085,

O. K. Balalaiev ${ }^{3}$, Cand. Sc. (Biol.), Senior Research

Fellow,

orcid.org/0000-0002-9389-4562,

V. L. Smiesova ${ }^{4}$, Cand. Sc. (Econ.), Assoc. Prof., orcid.org/0000-0002-0444-4659
1 - Dnipro University of Technology, Dnipro, Ukraine, e-mail:ma_riva@ukr.net

2 - National Metallurgical Academy of Ukraine, Dnipro, Ukraine

3 - M.S. Polyakov Institute of Geotechnical Mechanics of NASU, Dnipro, Ukraine

4 - State Higher Educational Institution "Ukrainian State University of Chemical Technology”, Dnipro, Ukraine

\title{
CLUSTERING AS A TOOL FOR MANAGING INDUSTRIAL ENTERPRISE
}

Purpose. Substantiation of methodological foundations for forming a cluster of industrial enterprises and establishing a system of relationships between their cluster groups.

Methodology. Specific analogue modelling techniques were used to identify the relations between manufacturing enterprises; economic and mathematical modelling was used to search for multilayered network communities.

Findings. A fundamentally new methodological basis has been proposed for identifying a cluster of industrial enterprises. This has been done through a comparison of the results of the three approaches to clustering. It has been revealed that hierarchical cluster analysis does not allow identifying similar groups of enterprises or relationships between them, since this approach lacks a single strict criterion for an optimal split of the dendrogram into clusters. The competitive approach of the geometric distance of neurons to objects, which is based on the technique of self-learning neural network and Kohonen's self-organizing maps, also identified a non-uniform cluster structure. The study proposes to form a cluster of industrial enterprises through the method of searching for communities in multilayered network graphs. This method was a breakthrough in building a cluster as a merger of extractive and processing industrial enterprises, together with academic and research institutions.

Originality. A new methodological approach to the formation of industrial enterprise cluster has been proposed, whose mathematical basis was developed by T. Kamada. This approach uses multiple object proximity matrices, which take into account supplier-consumer relationships, geographical distances, and patterns of ownership. It has been proved that this method for clustering is more advantageous, since it allows identifying the communities of enterprises, which are network analogues to a cluster; it also takes into account the relationships of the analysed metallurgical enterprises of the mining and processing industry with educational and research institutions of the enterprises. The development of these relationships creates the basis for the productive development, efficient operation and additional competitive advantages for industrial enterprises.

Practical value. Under conditions of a crisis in the metallurgical industry, it is recommended to create a cluster, which will significantly increase the competitiveness of each enterprise included in the cluster and fully use the potential of the metallurgical complex.

Keywords: cluster economy, clustering, industrial cluster, network community of enterprises

Introduction. In today's conditions, stable performance of industrial enterprises and their competitive advantages are only possible on the basis of the inevitable organisational and technical restructuring of the management mechanism in accordance with the up-to-date level of knowledge, technology, and organisation of activity. Most manufacturers are faced with the need for flexible adaptation to the changing market environment, globalisation, informatisation and regionalisation. They need to systematise and optimise all business processes in order to reduce total costs, review the organisation of logistics and actively implement the latest technologies and concepts of doing business. Among the variety of ways to develop the market, means of production, and new areas of activity, clustering is a priority as a tool for managing industrial enterprises. Today, the formation of clusters is a prospect for the further development of many entities at the micro and macro levels. Due to the rapid changes in market conditions, the study of today's clustering methods, comparison of the results obtained and identification of economic entities that can form a cluster of industrial enterprises, becomes a burning problem that needs urgent solution.

Literature review. A large number of publications have been devoted to the issue of cluster formation. The researchers focus on identifying the efficiency correlation between enterprises that have similar operating parameters; these correlation links may serve as a basis for the mutual integration of the en-

(C) Ivanova M.I., Faizova S. O., Boichenko M.V., Balalaiev O. K., Smiesova V. L., 2020 terprises. It should be noted that the interest of scientists has been directed to the search for these patterns at both macro and micro levels.

For example, the scientific approach to clustering of the countries of the world was substantiated in [1]. This approach is based on a neural network analysis that uses the self-organizing Kohonen maps. This analysis allows clustering and, accordingly, grouping the countries of the world according to similar patterns of economic processes; revealing explicit and implicit relationships between them; establishing the weight and significance of each link (neuron) in the formed clusters and their correspondence to the input parameters.

The methodology for formation of regional clusters, which takes into account the comparative economic advantages of the regions to ensure their sustainable economic development, was investigated by V. Glinskiy [2]. The author proved the inappropriateness of the regular regression model as it cannot be used in dynamics; he suggested eliminating this disadvantage by introducing the indicator of "cluster formation probability". The coefficients of industry specialisation of the regional economy were used as predictors (variables) in the regression equation. However, the author of the model did not take into account the geographical proximity of the regions, which affects the presentation of the results.

The problem of cluster formation at the enterprise level has been investigated by domestic and foreign scientists. In particular, the Russian scientists A. Babkin, T. Kudryavtseva, S. Utkina used the category of "virtual enterprise" in the process of constructing a cluster model [3]. This approach made it 
possible to combine multiple consumers into one virtual consumer, thus simplifying the visualisation and analysis of the resulting cluster formation. This approach was further developed by G. Jucevicius, who focused on the formation of clusters in developing countries. The scientist has highlighted the factors that contribute to and hinder this process. However, the scientist does not propose tools for assessing the possibility of cluster formations under the conditions of internationalisation and globalisation of the economy [4].

Lu Yi focused on the problem of 'a transfer' of small enterprises into industrial clusters. The researcher concluded that politics, market conditions, governance, finance and technological progress are key factors that influence making decisions on the integration of small businesses into inter-firm alliances [5].

Industrial symbiosis as a type of a cluster was studied in detail by B. Baldassarre [6]. This scientist shares the opinion of V. Glinskiy that the formation of a cluster is a prerequisite for sustainable development, which, to his mind, is based on two concepts - industrial ecology and circular economy. He carried out a comparative analysis of these concepts, which revealed that they are complementary and should be applied simultaneously for a full description of the cluster. V. Kayvanfar, in his turn, focused on the analysis of interconnections within an industrial cluster from the point of view of supply chain management (SCM) [7]. The scientist constructed a model of economic activity of enterprises using a two-stage model of stochastic programming, followed by the use of acceleration strategies of Benders decomposition. The scientist considers the findings as a basis for making managerial decisions to minimize the total cost of a particular supply chain. However, the issue of evaluating the performance efficiency of the formed cluster remained unresolved. Therefore, in [8] these indicators were formalised; among them, the indicators of business activity and socio-economic effect were singled out.

The clustering process is the construction of an economic, organisational and legal model for the merger of enterprises and the development of integration processes; this involves improving the effectiveness of organisational innovations, making effective management decisions, identifying the main motives that encourage economic entities to establish control over the functioning of other enterprises in order to optimise the market mechanism for resource redistribution [9]. The effectiveness of clustering is affected by low qualifications of the workforce and insufficient level of its reproduction, lack of available capital, poor technologies, insufficient level of the educational and research system, and imperfect institutions. At the same time, clustering ensures an increase in the efficiency of interaction between enterprises, financial and research institutions and the government, an active use of the most important interrelations in the spheres of technology, qualifications, information, marketing and consumer demands, which are characteristic of the whole complex of enterprises and industries. These interrelations influence the direction and pace of innovation, as well as the competitiveness of end products. Therefore, there is a need for a further scientific insight into the methodology of clustering.

Unsolved aspects of the problem. Despite considerable achievements of scientists in the investigation of clustering, the methodological base for the formation of industrial enterprise clusters remains underdeveloped in the current scientific publications; also, there is no single approach to the methods and tools that can be used to identify the enterprises that can be combined in a cluster.

Purpose. The purpose of the article is to substantiate the methodological base of forming a cluster of industrial enterprises and establish a system of relationships between their cluster groups. To achieve this, a cluster analysis of enterprises was carried out by the hierarchical, competitive and graph methods; the obtained results were compared; the advantages and disadvantages of each method, when used for clustering industrial enterprises, were revealed; a new technique for a cluster analysis has been proposed, which is based on the search for communities in multilayer network graphs; entities that can form a cluster and establish partnership relations were identified by studying Ukraine's industrial enterprises.

Methods. For a more thorough study, the three methods of cluster analysis were compared. The obtained results can be used to construct a cluster through the merge of industrial enterprises of the extractive and processing industry.

In Approach 1, a hierarchical cluster analysis was conducted to organise multiple objects into an assigned number of clusters, using the raw data. It was based on the assumptions formulated by B. Duran and P. Odell: the object belongs to only one subset and the objects belonging to the same cluster are similar. At the same time, objects belonging to different clusters are dissimilar.

In Approach 2, a competitive method of the geometric proximity of neurons to objects was used. This approach is based on the neural network technology of self-learning that uses the Kohonen self-organizing maps (SOM). The Kohonen map algorithm is based on the clustering of multidimensional vectors that characterise the objects under study using a given feature space. As a rule, all nodes in this neural network are arranged in the form of a certain organisational structure. When applied, the latter is preferably a two-dimensional network [10].

Approach 3 is a new clustering method proposed by the authors for finding communities in multilayered network graphs. This approach simultaneously considers the similarity of objects in several spaces that reflect various manifestations of economic activity of enterprises. The method, developed by T. Kamada, is based on a fundamentally different methodology for analysing multidimensional data, the socalled graph theory, according to which the connections between enterprises are presented as adjacency matrices [11, 12].

The main sources of statistics were indicators of the Stock Market Infrastructure Development Agency of Ukraine [13]. For the convenience of analysis, each enterprise was assigned a conditional number.

Results. The results of hierarchical cluster analysis were obtained using the SPSS 22, a statistical software package developed by Achim Buehl and Peter Zoefel (A. Bühl and P.Zöfel). As indicators of system units, eight indicators were used to characterize the financial and economic activity of the enterprise: net sales revenue (Return), operating expenses (Charge), net profit (Gain), assets (Asset), non-current assets (Nasset), current assets (Casset), number of staff (Staff), cost of sales (Cost). The names of the enterprises that form a cluster were the observation label or text change.

Dendrograms are obtained using the method of intergroup relations. This allows identifying merged clusters and presenting proximity matrices that are constructed by squared Euclidean distances. In this case, at the maximum distance between the clusters, two unequal groups of enterprises were figured out: the first group included No. 8 and No. 15; the second group involved all the remaining enterprises (Table 1). This result is explained by the use of data for one-year's period only. This has led to the fact that most businesses are little different from each other and easily fall into one megacluster.

The results obtained in the hierarchical cluster analysis were based on economic indicators collected over eight years; they cannot be recommended for use because of the peculiarities of the analysed data; moreover, the above method has a fundamentally significant drawback, which is the absence of a single, rigorous, and mathematically proved criterion for an optimal split of a dendrogram into clusters in the case their number is not known in advance. In addition, agglomerative clustering algorithms (except the single linkage clustering method) include the objects into a cluster, 
Table 1

Results obtained in the cluster hierarchical analysis of cluster formation (compiled by the authors)

\begin{tabular}{|c|c|c|}
\hline Cluster & Number & Name of Company \\
\hline \multirow[t]{2}{*}{ First } & No. 8 & JSC Marhanets Mining and Processing Plant \\
\hline & No. 15 & PJSC Ukrainian Graphite \\
\hline \multirow[t]{29}{*}{ Second } & No. 1 & $\begin{array}{l}\text { PJSC Electrometallurgical Plant } \\
\text { Dniprospetsstal named after A. N. Kuzmin }\end{array}$ \\
\hline & No. 2 & JSC Zaporizhzhia Ferroalloy Plant \\
\hline & No. 3 & $\begin{array}{l}\text { Zaporizhzhia Titanium and Magnesium } \\
\text { Combine LLC }\end{array}$ \\
\hline & No. 4 & $\begin{array}{l}\text { Zaporizhzhia Aluminium Production } \\
\text { Combine JSC }\end{array}$ \\
\hline & No. 5 & PJSC Chasivoyar Refractory Plant \\
\hline & No. 6 & Tsentralvis Production Ukraine PJSC \\
\hline & No. 7 & JSC Nikopol Ferroalloy Plant \\
\hline & No. 9 & $\begin{array}{l}\text { PJSC Ordzhonikidze Mining and Processing } \\
\text { Plant }\end{array}$ \\
\hline & No. 10 & PJSC Zaporizhvohnetryv \\
\hline & No. 11 & PJSC Novotroitsk Mine Management \\
\hline & No. 12 & PJSC Tovkachivskyi GZK \\
\hline & No. 13 & Enerhomashspetsstal PJSC \\
\hline & No. 14 & PJSC Poltava Mining and Processing Plant \\
\hline & No. 16 & Keramet PJSC \\
\hline & No. 17 & PJSC Non-ferrous Metal Processing Plant \\
\hline & No. 18 & Zaporizhskloflus JSC \\
\hline & No. 19 & PJSC Velykoanadolskyi Refractory Plant \\
\hline & No. 20 & PJSC Vatutin Refractory Works \\
\hline & No. 21 & Zaporizhzhia Vtormet PJSC \\
\hline & No. 22 & PJSC Novopoltavskyi Karier \\
\hline & No. 23 & PJSC Tokmak Forging and Stamping Plant \\
\hline & No. 24 & PJSC Dokuchaiev Flux-Dolomite Works \\
\hline & No. 25 & PJSC Plywood and boards \\
\hline & No. 26 & PJSC Mukachevo Forestry Complex \\
\hline & No. 27 & JSC Kremenchuk karieroupravlinnia Quartz \\
\hline & No. 28 & PJSC Lviv Coal Company \\
\hline & No. 29 & Trubostal NPO LLC \\
\hline & No. 30 & INTERPIPE STAL LLC \\
\hline & No. 31 & Zaporizhkoks PJSC \\
\hline
\end{tabular}

Note: The enterprise numbers listed in the table above will be used hereinafter

which are grouped around the identified cluster centre. In this case, the produced clusters would have the shape of hyperspheres, and the cluster structure changes depending on the radius of the circle. This does not allow solving the problem unambiguously.

According to Approach 2 that uses the Kohonen self-organizing maps, an input matrix was formed, consisting of $31 \mathrm{ob}-$ servation vectors (by the number of enterprises) with a dimension of 40 ( 8 indicators over the last 5 years).

All the variables were pre-standardized by subtracting the mean from the sample items and dividing by the standard deviation. Therefore, for all input variables, the mean is 0 and the standard deviation is 1 . The neurons in the Kohonen layer were arranged according to a hexagonal topology of $50 \times 50$ neurons. The proximity measure was the Euclidean distance metric. A Gaussian function was used for smoothing the kernel. Initial learning rate was $\mu=0.1$. The learning was performed using stochastic gradient descent.

To robust the cluster, an iterative procedure for a phase adjustment of the clusters [14] was initiated by transferring the winning neurons with a correction radius $\sigma_{C R}=0.7$ over 100 epochs. The resulting U-matrix (Fig. 1) shows a large cluster of enterprises in the centre of the map. All the other objects do not form clusters with each other.

SOM is primarily used to visualize the link densities between multidimensional object on a flat map and to identify the agglomerated neural nodes into which the investigated subset of objects falls. The distribution of points on the map allows roughly estimating the topography of multidimensional data. In addition, the SOM algorithm is prone to find rounded cluster zones.

For more accurate identifying of the groups of enterprises that tend to form an arbitrary-shaped cluster, the DBSCAN algorithm (Density-based spatial clustering of applications with noise) was used, which had been proposed by M. Ester, H.-P. Kriegel, J. Sander and X.Xu. Identification of clusters containing more than one object is only possible if there is one neighbour $(m=1)$ and a sufficiently sized $\varepsilon$-neighbourhood (Fig. 2). This pattern is typical of the elongated closely spaced agglomerations in the data.
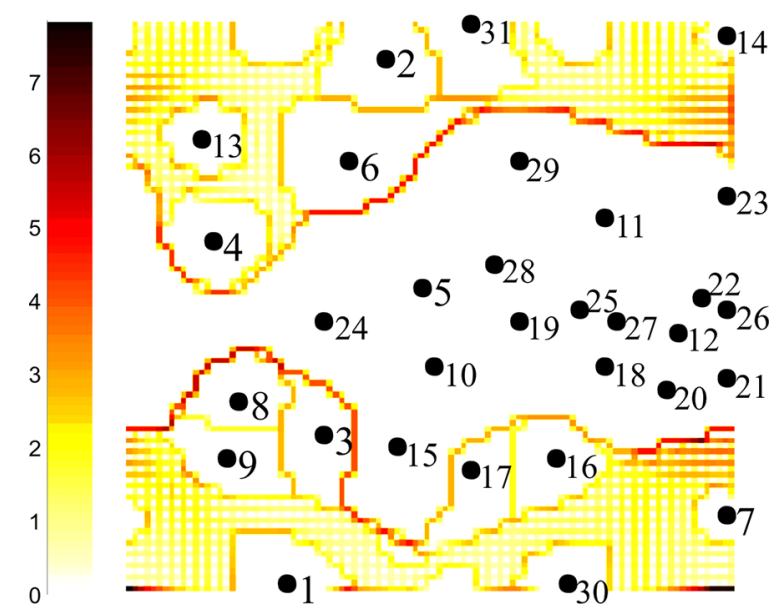

Fig. 1. Self-organising map that represents the proximity of enterprises, constructed using five-year-period's indicators of their activity (colour intensity shows distances between the objects in multidimensional space)

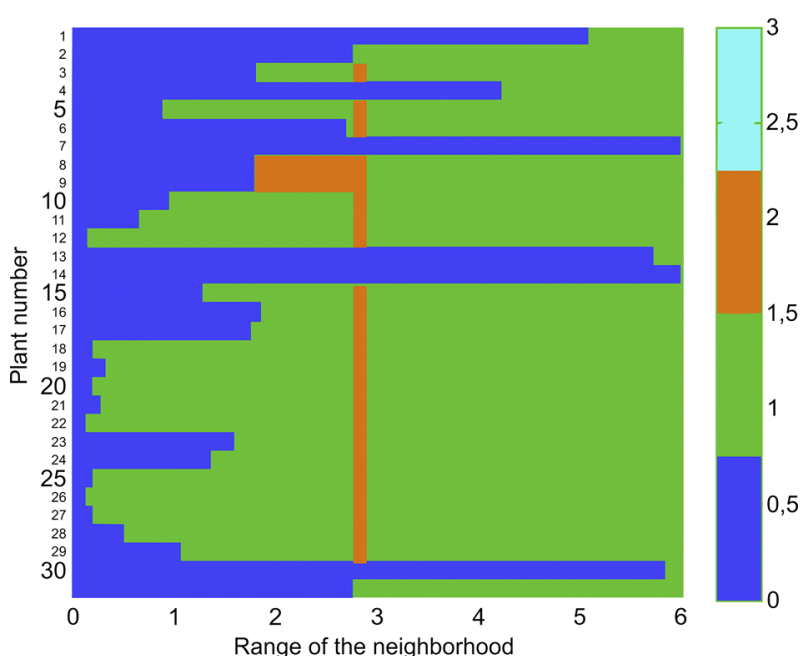

Fig. 2. Enterprises that tend to cluster depending on a search radius 
Thus, according to breadth-first search for traversing the graph with restrictions, it is advisable to combine the following 17 enterprises into a cluster: No. 5, No. 10, No. 11, No. 12, No. 15 , No. 18 , No. 19 , No. 20 , No. 21 , No. 22 , No. 23 , No. 24, No. 25, No. 26, No. 27, No. 28, and No. 29.

In Approach 3, based on identifying communities in multilayered network graphs, the following matrices were chosen for analysis:

1) the supplier-consumer relationship matrix (Links);

2) weighted geographic distance matrix (Distance);

3) matrix of forms of ownership (Property), which includes several state-owned enterprises and those belonging to financial-industrial groups.

Approach 3 implies constructing weighted matrices that consider each layer individually and demonstrate the way the nodes (their communities) are connected within the layer. A number of restrictions are taken into account: it is assumed that too long distances between enterprises do not contribute to their integration due to inevitable logistics cost. Therefore, only enterprises spaced within $600 \mathrm{~km}$ are included in the weighted distance matrix, other matrix elements being equal to ' 0 '. The distance of $600 \mathrm{~km}$ was found as the histogram minimum (Fig. 3).

It was the cross-correlation coefficients significant at the $p<$ $<0.01$ level which were included in the enterprise metrics matrix. With these requirements, the coefficient in the module exceeds 0.77 . Hence, the model only takes into account $10.4 \%$ of all possible correlations between enterprises, which are represented by arcs on the corresponding graphs (Fig. 4). The struc-

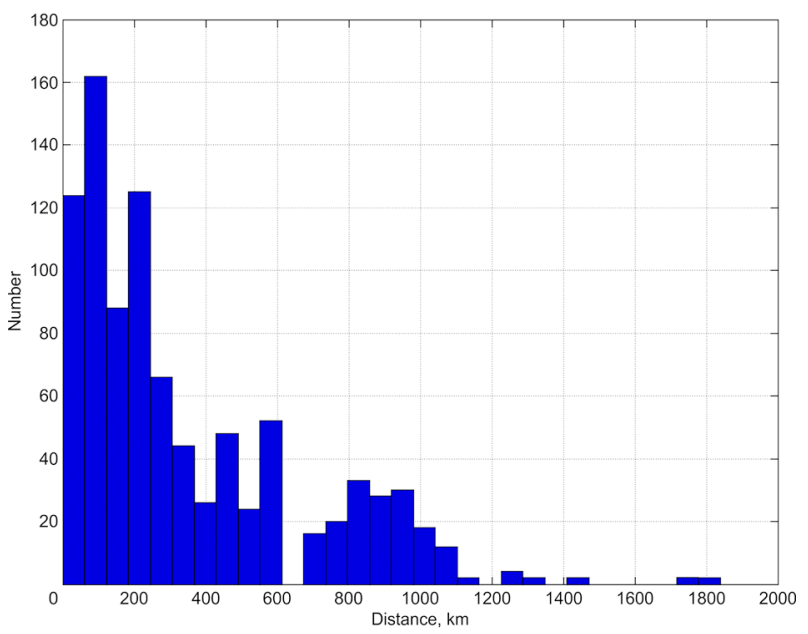

Fig. 3. Histogram of the distribution of distances between enterprises
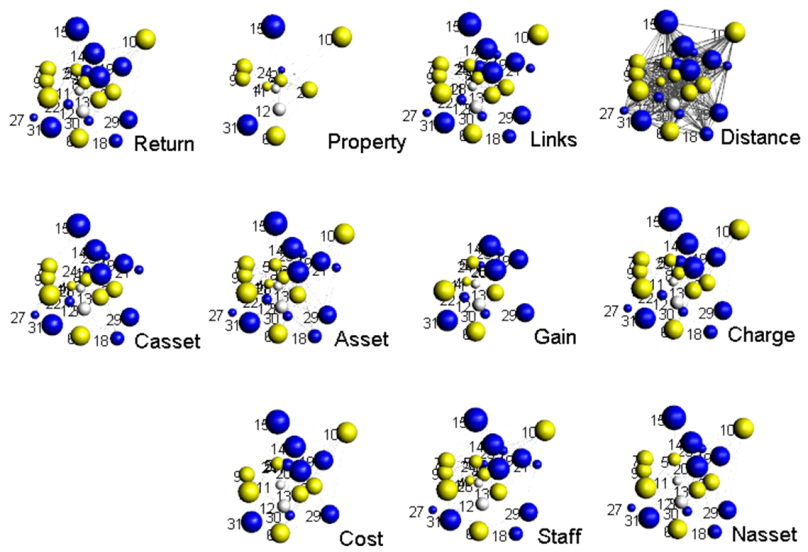

Fig. 4. Network graphs of individual layers of enterprise connections ture of the presented data corresponds to a multidimensional multilayer network. Each of the presented adjacency matrices can be displayed as a network graph in a separate layer.

The mathematical basis for the analysis of multilayer networks has been developed relatively recently [12]. Network clustering is possible by searching for communities (groups of nodes) that have more edges with each other than with other nodes. The community structure analysis is based on optimisation of the Girvan - Newman $Q$ modularity, which is equal to the probability of finding the same community structure in a randomly formed network [11].

Modularity is calculated as the ratio of the sum differences between the actual and the expected number of edges that connect pairs of vertices within a cluster, in a randomly generated graph of the same dimensions. In other words, it is a measure of the deviation of the link density in the network from the density distributed randomly.

The three-dimensional visualization of the multilayered network presents three communities (Fig. 5).

The number of communities and the modularity of the individual layers vary from 2 to 5 and from 0.017 to 0.566 , respectively (Table 2).

Aggregated modularity is quite low $Q=0.072$ and approaches the standard confidence level of 0.05 , which indicates a confident combination of nodes in the community.

Since the number of vertices of the graph does not exceed 100 , the geometric location of the network nodes is optimized according to the minimum internal energy of the spring-embedded particle system using a force algorithm developed by T. Kamada and S. Kawai.

In this algorithm, the graph is a system of springs, but if the pair of vertices is geometrically spaced very close or far apart, then the force of attraction or repulsion is applied to the vertices. The algorithm searches for values of variables that minimise the function of the potential energy $E\left(x_{1}, x_{2}, \ldots, x_{n}, y_{1}\right.$, $\left.y_{2}, \ldots, y_{n}, z_{1}, z_{2}, \ldots, z_{n}\right)$; for the 3D model it is Cartesian coordinates of the nodes, since at a global (single or absolute for a given function) minimum, all the individual derivatives of the energy function are 0 .

Discussion. Hence, Approach 3, which considers multilayered network communities, allowed an identification of the following three enterprise communities. The first community includes enterprises No. 1 , No. 2 , No. 3 , No. 4 , No. 5 , No. 6 , No. 7 , No. 8 , No. 9 , No. 10 , No. 11.

The second network consists of enterprises No. 12, No. 14 , No. 16 , No. 20, No. 25 , No. 26 , No. 28.

Enterprises No. 13 , No. 15 , No. 17 , No. 18 , No. 19 , No. 21 , No. 22 , No. 23 , No. 24 , No. 27 , No. 29 , No. 30 , No. 31 fall into the third cluster formation.

In our opinion, it is relevant to use the results obtained by applying Approach 3 to search for multilayered network communities; also, enterprises that formed the first community are prone to form a cluster that will aggregate the above enterpris-

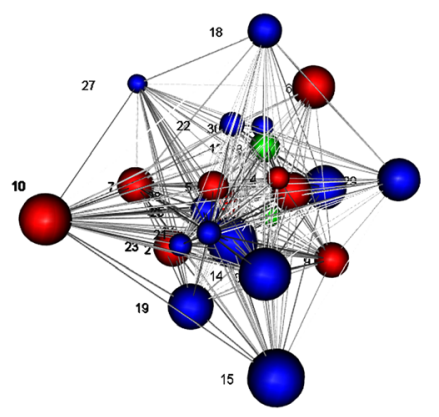

Fig. 5. 3D model of a multidimensional network of enterprise connections (communities vary in colour, the dimension of a node is proportional to its level, i.e. the number of links with other nodes) 
End identification of cluster-prone communities

\begin{tabular}{|c|c|c|c|c|c|c|c|c|c|c|c|c|}
\hline Enterprise No. & Distance & Links & Property & Return & Charge & Gain & Asset & Casset & Nasset & Staff & Cost & Aggregation \\
\hline No. 1 & 2 & 2 & 0 & 1 & 3 & 2 & 2 & 1 & 3 & 1 & 1 & 1 \\
\hline No. 2 & 2 & 3 & 1 & 1 & 1 & 0 & 0 & 2 & 1 & 0 & 1 & 1 \\
\hline No. 3 & 2 & 3 & 0 & 0 & 0 & 0 & 2 & 1 & 3 & 0 & 0 & 1 \\
\hline No. 4 & 2 & 0 & 2 & 0 & 0 & 2 & 3 & 4 & 0 & 2 & 0 & 1 \\
\hline No. 5 & 2 & 2 & 0 & 1 & 3 & 3 & 2 & 0 & 3 & 1 & 0 & 1 \\
\hline No. 6 & 2 & 2 & 1 & 1 & 1 & 2 & 2 & 1 & 3 & 4 & 1 & 1 \\
\hline No. 7 & 2 & 3 & 1 & 1 & 0 & 0 & 1 & 2 & 2 & 1 & 0 & 1 \\
\hline No. 8 & 2 & 3 & 1 & 2 & 1 & 0 & 1 & 3 & 0 & 1 & 0 & 1 \\
\hline No. 9 & 2 & 3 & 1 & 3 & 1 & 0 & 1 & 2 & 1 & 1 & 0 & 1 \\
\hline No. 10 & 2 & 2 & 3 & 1 & 1 & 0 & 2 & 0 & 3 & 1 & 1 & 1 \\
\hline No. 11 & 0 & 3 & 1 & 1 & 1 & 3 & 2 & 1 & 2 & 5 & 1 & 1 \\
\hline No. 12 & 3 & 1 & 2 & 1 & 2 & 3 & 2 & 2 & 3 & 3 & 1 & 2 \\
\hline No. 13 & 2 & 1 & 0 & 1 & 1 & 2 & 1 & 1 & 1 & 1 & 1 & 3 \\
\hline No. 14 & 2 & 3 & 0 & 1 & 1 & 2 & 2 & 1 & 3 & 2 & 1 & 2 \\
\hline No. 15 & 2 & 3 & 2 & 1 & 1 & 0 & 2 & 2 & 3 & 1 & 1 & 3 \\
\hline No. 16 & 3 & 2 & 0 & 4 & 4 & 0 & 2 & 1 & 0 & 5 & 0 & 2 \\
\hline No. 17 & 2 & 5 & 0 & 0 & 0 & 0 & 0 & 0 & 0 & 2 & 2 & 3 \\
\hline No. 18 & 2 & 5 & 0 & 1 & 2 & 0 & 2 & 2 & 3 & 1 & 0 & 3 \\
\hline No. 19 & 2 & 1 & 0 & 1 & 1 & 2 & 2 & 3 & 3 & 2 & 1 & 3 \\
\hline No. 20 & 3 & 1 & 0 & 1 & 1 & 3 & 2 & 1 & 3 & 2 & 1 & 2 \\
\hline No. 21 & 2 & 2 & 0 & 0 & 0 & 0 & 1 & 3 & 0 & 1 & 0 & 3 \\
\hline No. 22 & 2 & 3 & 0 & 1 & 1 & 1 & 2 & 2 & 0 & 0 & 0 & 3 \\
\hline No. 23 & 2 & 4 & 0 & 0 & 0 & 4 & 1 & 4 & 1 & 2 & 0 & 3 \\
\hline No. 24 & 2 & 3 & 1 & 0 & 0 & 4 & 0 & 2 & 0 & 6 & 2 & 3 \\
\hline No. 25 & 2 & 1 & 0 & 1 & 1 & 0 & 0 & 0 & 0 & 0 & 1 & 2 \\
\hline No. 26 & 1 & 1 & 2 & 2 & 0 & 2 & 0 & 0 & 0 & 3 & 0 & 2 \\
\hline No. 27 & 2 & 3 & 0 & 4 & 4 & 0 & 2 & 2 & 3 & 0 & 0 & 3 \\
\hline No. 28 & 1 & 3 & 0 & 0 & 0 & 0 & 3 & 4 & 0 & 6 & 0 & 2 \\
\hline No. 29 & 2 & 4 & 0 & 1 & 1 & 1 & 2 & 1 & 3 & 4 & 1 & 3 \\
\hline No. 30 & 2 & 4 & 0 & 3 & 1 & 1 & 2 & 0 & 3 & 0 & 0 & 3 \\
\hline No. 31 & 2 & 3 & 3 & 1 & 1 & 3 & 2 & 1 & 3 & 2 & 1 & 3 \\
\hline Modularity & 0.017 & 0.295 & 0.304 & 0.164 & 0.116 & 0.566 & 0.157 & 0.314 & 0.138 & 0.137 & 0.104 & 0.072 \\
\hline
\end{tabular}

es, educational institutions and innovative bodies. Identifying a cluster is the basis for its productive functioning, development and obtaining unique competitive advantages. In particular, forming and establishing partnerships will significantly increase the competitiveness of each enterprise in the cluster and enhance the potential of the metallurgical complex. For example, it opens up opportunities for more extensive use of up-to-date $R \& D$, advanced production technologies, and new types of economic resources; it allows manufacturing innovative products, improvement of workpower qualifications, obtaining external sources of financing, crediting and investing; solving the problem of resources; expanding markets, and others. Therefore, this will be the basis for improving the efficiency of each cluster member.

Conclusions. The relevancy of the formation of industrial clusters is proved by the results of the cluster analysis. The authors have proposed a hierarchical cluster analysis and used it to identify two unequal groups of enterprises: the first group included two companies; all the remaining enterprises fall into the second group, which is explained by the use of data for only one-year's period. An addition of metrics over five years in Approach 2 (the competitive approach of geometric proximity of neurons to objects, which is based on neural network technology of self-learning and uses Kohonen self-organizing maps) does not fundamentally change the cluster structure. Only the use of a completely new clustering method (Approach 3), i.e. the search for multilayer network communities based on the modularity of the graph, which involves the use of multiple object proximity matrices (supplier-consumer relationships, geographical distances, patterns of ownership) allowed distinguishing three enterprise communities that are network analogues to clusters.

Considering the crisis of metallurgical enterprises functioning, we recommend forming a cluster that will include metallurgical enterprises of mining and processing industry and academic and research institutions; this will provide a good basis for the effective development, efficient performance and obtaining additional competitive advantages. The formation and establishment of partnerships will significantly increase the competitiveness of each enterprise in 
the cluster and realize the potential of the metallurgical complex.

\section{References.}

1. Smiesova, V. L., \& M'iachyn, V. H. (2018). Neural network approach to clustering countries by iIndicators characterizing the processes of formation and implementation of economic interests. Naukovyi Visnyk Uzhhorodskoho Natsionalnoho Universytetu. Seriia: Mizhnarodni ekonomichni vidnosyny ta svitove hospodarstvo, 19(3), 49-57.

2. Glinskiy, V., Serga, L., Chemezova, E., \& Zaykov, K. (2016). Clusterization Economy as a Way to Build Sustainable Development of the Region. Procedia CIRP, 40, 324-328. https://doi.org/10.1016/j.procir.2016.01.050.

3. Babkin, A., Kudryavtseva, T., \& Utkina, S. (2013). Formation of Industrial Clusters Using Method of Virtual Enterprises. Procedia Economics and Finance, 5, 68-72. https://doi. org/10.1016/S2212-5671(13)00011-7.

4. Jucevicius, G., \& Grumadaite, K. (2015). Patterns for Cluster Emergence in Latecomer Economies. Procedia-Social and Behavioral Sciences, 213, 198-203. https://doi.org/10.1016/j. sbspro.2015.11.426.

5. Luyi, C., Yuan, Z., Dillon, Z., \& Lan, X. (2017). Clustering enterprises into eco-industrial parks: Can interfirm alliances help small and medium-sized enterprises? Journal of Cleaner Production, 168, 1070-1079. https://doi.org/10.1016/j. jclepro.2017.09.104.

6. Baldassarre, B., Schepers, M., Bocken, N., Cuppen, E., \& Calabretta, G. (2019). Industrial Symbiosis: towards a design process for eco-industrial clusters by integrating Circular Economy and Industrial Ecology perspectives. Journal of Cleaner Production, 216, 446-460. https://doi.org/10.1016/j. jclepro.2019.01.091.

7. Kayvanfar, V., Moattar Husseini, S.M., Sajadieh Mohsen, S., \& Karimi, B. (2018). A multi-echelon multi-product stochastic model to supply chain of small-and-medium enterprises in industrial clusters. Computers \& Industrial Engineering, 8(115), 69-79. https://doi.org/10.1016/j.cie.2017.11.003.

8. Ivanova, M. I. (2017). Formalization of performance indicators in industrial logistics clusters. Visnyk Natsionalnoho Universytetu "Lvivska politekhnika". Seriia: Menedzhment ta pidpryiemnytstvo $v$ Ukraini: etapy stanovlennia i problemy rozvytku. (Pidpryiemnytstvo), 875, 147-152.

9. Pjatak, I. V. (2015). Enterprise clustering as a factor of innovative and integration processes of regional economy development. Visnyk Berdianskoho Universytetu Menedzhmentu $i$ Biznesu, 1, 119-122.

10. Kohonen, T. (2013). Essentials of the self-organizing map. Neural Networks, 37, 52-65. https://doi.org/10.1016/i.neunet.2012.09.018.

11. Fortunato, S., \& Hric, D. (2016). Community detection in networks: A user guide. Physics Reports, 659, 1-44. https://doi. org/0.1016/j.physrep.2016.09.002.

12. Kivelä, M., Arenas, A., Barthelemy, M., Gleeson, J.P., Moreno, Y., \& Porter, M. A. (2014). Multilayer networks. Journal of Complex Networks, 2(3), 203-271. https://doi. org/10.1093/comnet/cnu016.

13. Stock market infrastructure development agency of Ukraine (n.d). Retrieved from: http://www.smida.gov.ua/.

14. Manukyan, N., Eppstein, M.J., \& Rizzo, D. M. (2012). Data-driven cluster reinforcement and visualization in sparsely-matched self-organizing maps. Neural Networks and learning Systems, IEEE Transactions on, 23(5), 846-852. https:// doi.org/10.1109/TNNLS.2012.2190768.

\section{Кластеризація як інструмент управління промисловими підприємствами}

\author{
М. І. Іванова ${ }^{1}$, С. О. Фаізова ${ }^{2}$, М. В. Бойченко ${ }^{1}$, \\ О. К. Балалаєв ${ }^{3}$ В. Л. Смєсова
}

1 - Національний технічний університет «Дніпровська політехніка», м. Дніпро, Україна, e-mail: ma_riva@ukr.net 2 - Національна металургійна академія України, м. Дніпро, Україна

3 - Інститут геотехнічної механіки імені Н. С. Полякова НАН України, м. Дніпро, Україна

4 - Державний вищий навчальний заклад «Український державний хіміко-технологічний університет», м. Дніпро, Україна

Мета. Обгрунтування методичних підходів до формування кластера промислових підприємств і встановлення системи зв'язків між їх кластерними групами.

Методика. Використані спеціальні методи аналогового моделювання для виявлення зв'язків виробничих підприємств, а також методи економіко-математичного моделювання для пошуку спільнот багатошарових мереж.

Результати. На принципово новій методологічній основі розкрито підхід до виявлення кластера промислових підприємств. Для цього порівняні результати трьох підходів до кластеризації. Встановлено, що ієрархічний кластерний аналіз не дозволяє виокремити рівнозначні групи підприємств і виявити зв'язки між ними, оскільки за даного підходу відсутній єдиний суворий критерій оптимального розподілу дендрограми на кластери. Конкурентний підхід геометричної близькості нейронів до об'єктів, що грунтується на нейромережевій технології самостійного навчання й самоорганізованих картах Кохонена, також дозволив виділити нерівномірну кластерну структуру. Уперше рекомендовано використовувати для формування кластеру промислових підприємств метод пошуку спільнот у багатошарових мережевих графах. Цей метод дозволив уперше побудувати кластер, що передбачає об'єднання промислових підприємств добувної й переробної галузі, навчальних закладів і науково-дослідних структур.

Наукова новизна. Запропоновано використовувати новий методологічний підхід до формування кластерів промислових підприємств, математичну основу для якого розробив Т. Камада. Цей підхід заснований на використанні множини матриць близькості об'єктів, що враховує зв'язки «постачальник - споживач», географічні відстані, форми власності. Доведено, що перевагою кластеризації на основі даного методу є можливості виокремлення спільноти підприємств, що є мережевими аналогами кластерів, і врахування зв'язків проаналізованих металургійних підприємств добувної й переробної галузі з навчальними закладами, науково-дослідними структурами підприємств. Розвиток цих зв'язків формує засади для продуктивного розвитку, функціонування та отримання додаткових конкурентних переваг промисловими підприємствами.

Практична значимість. В умовах кризи функціонування металургійних підприємств рекомендується сформувати кластер, що дозволить значно підвищити конкурентоспроможність кожного підприємства, яке входить до його складу, і більш ефективно реалізувати потенціал металургійного комплексу.

Ключові слова: кластерна економіка, кластеризація, промисловий кластер, мережева спільнота підприємств

\section{Кластеризация как инструмент управления промышленными предприятиями}

\section{М. И. Иванова ${ }^{1}$, С. А. Фаизова ${ }^{2}$, М. В. Бойченко ${ }^{1}$, А. К. Балалаев ${ }^{3}$, В. Л. Смесова ${ }^{4}$}

1 - Национальный технический университет «Днепровская политехника», г. Днепр, Украина, e-mail: ma_riva@ ukr.net 
2 - Национальная металлургическая академия Украины, г. Днепр, Украина

3 - Институт геотехнической механики имени Н. С. Полякова НАН Украины, г. Днепр, Украина

4 - Государственное высшее учебное заведение «Украинский государственный химико-технологический университет», г. Днепр, Украина

Цель. Обоснование методических основ формирования кластера промышленных предприятий и выявление системы связей между их кластерными группами.

Методика. Использованы специальные методы аналогового моделирования для выявления связей производственных предприятий, а также методы экономикоматематического моделирования для поиска сообществ многослойных сетей.

Результаты. На принципиально новой методологической основе раскрыт подход к выявлению кластера промышленных предприятий. Для этого осушествлено сравнение результатов применения трех подходов к кластеризации. Установлено, что иерархический кластерный анализ не позволяет выделить равнозначные группы предприятий и выявить связи между ними, поскольку при таком подходе отсутствует единый строгий критерий оптимального распределения дендрограммы на кластеры. Конкурентный подход геометрической близости нейронов к объектам, основанный на нейросетевой технологии самостоятельного обучения и самоорганизующихся картах Кохонена, также позволил выделить неравномерную кластерную структуру. Впервые рекомендуется использовать для формирования кластера промышленных предприятий метод поиска сообшеств в многослойных сетевых графах. Этот метод позволил впервые построить кластер, который предусматривает объединение промышленных предприятий добывающей и перерабатывающей отрасли, учебных заведений и научно-исследовательских структур.

Научная новизна. Предложен для применения новый методологический подход к формированию кластеров промышленных предприятий, математическую основу для которого разработал Т. Камада. Этот подход основан на использовании множества матриц близости объектов, которое учитывает связи «поставщик - потребитель», географические расстояния, формы собственности. Доказано, что преимущество кластеризации на основе данного метода - возможности выделения сообщества предприятий, являющихся сетевыми аналогами кластеров, и учета связей проанализированных металлургических предприятий добывающей и перерабатывающей отрасли с учебными заведениями, научно-исследовательскими структурами предприятий. Развитие этих связей формирует основы для продуктивного развития, функционирования и получения дополнительных конкурентных преимуществ промышленными предприятиями.

Практическая значимость. В условиях кризиса функционирования металлургических предприятий рекомендуется сформировать кластер, который позволит значительно повысить конкурентоспособность каждого предприятия, входящего в его состав, и более эффективно реализовать потенциал металлургического комплекса.

Ключевые слова: кластерная экономика, кластеризация, промышленный кластер, сетевое сообщество предприятий

Recommended for publication by A.B. Bardas, Doctor of Economic Sciences. The manuscript was submitted 16.09.19. 